BIS

Working paper No. 38

\title{
INTERNATIONAL AGREEMENTS IN THE AREA OF BANKING AND FINANCE: ACCOMPLISHMENTS AND OUTSTANDING ISSUES
}

by

William R. White

October 1996

BANK FOR INTERNATIONAL SETTLEMENTS

Monetary and Economic Department

BASLE 
BIS Working Papers are written by members of the Monetary and Economic Department of the Bank for International Settlements and published by the Bank. The papers are on subjects of topical interest and are technical in character. The views expressed in them are those of their authors and not necessarily the views of the BIS.

(C) Bank for International Settlements 1996 CH-4002 Basle, Switzerland

All rights reserved. Brief excerpts may be reproduced or translated provided the source is stated.

ISSN 1020-0959 


\title{
INTERNATIONAL AGREEMENTS IN THE AREA OF BANKING AND FINANCE: ACCOMPLISHMENTS AND OUTSTANDING ISSUES*
}

by

\author{
William R. White
}

October 1996

\begin{abstract}
The deregulation of domestic financial markets, in association with technological progress, has led to an explosion of cross-border financial transactions and the cross-border establishment of premises. In turn, this has led to a need for international agreements on how the business of international finance and banking should be conducted. Private and public sector bodies have generally both been actively involved, but leadership has varied depending on the purpose of the agreement in question. Agreements to facilitate the conduct of cross-border financial transactions have in large measure been driven by private sector agents. Conversely, agreements to deliberately encourage the expansion of crossborder competition and to promote and maintain financial stability have been led by the public sector given the possibility of significant economic externalities. Many agreements to promote financial stability have been reached by committees operating at the Bank for International Settlements under the aegis of the Governors of the Group of Ten. Such agreements have moral authority, being based on discussions among representatives of sovereign states, but are nevertheless enforceable only by domestic legislation or regulation.
\end{abstract}

\footnotetext{
* I would like to thank, without implicating them and in no particular order, Gregor Heinrich, Fred Adelmann, Daniel Lefort, Paul Van den Bergh, Charles Freeland, Svein Andresen, Claudio Borio, Jean Kertudo and Serge Jeanneau.
} 



\section{Contents}

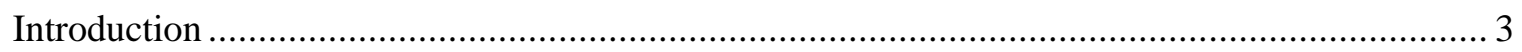

1. Trends in banking and finance and the need for international agreements ......................... 4

2. Agreements to facilitate the conduct of cross-border business....................................... 8

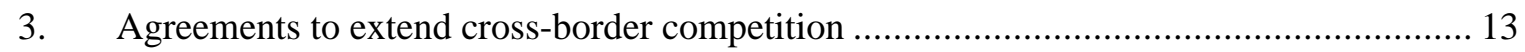

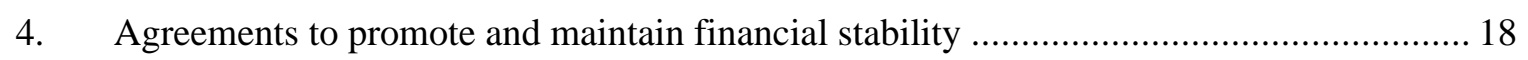

4.1 The purpose of international agreements ...................................................... 18

4.2 The process of achieving agreement ........................................................ 19

4.3 Specific agreements to foster financial stability ......................................... 22

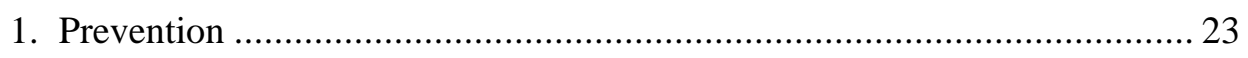

2. Crisis management and crisis resolution.............................................. 29

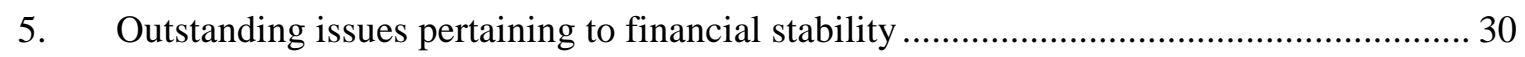

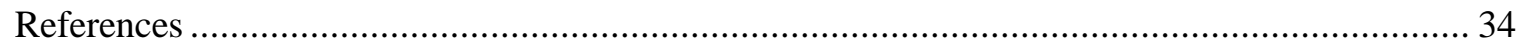





\section{Introduction}

At its most fundamental level, international banking and finance involves two things: cross-border financial transactions and associated payments, and the cross-border establishment of premises. In recent years there has been an explosion in both types of activity and, with it, the need for international agreements as to how the business of international banking and finance should be conducted. It would be impossible in one paper to provide a comprehensive survey and assessment of all the developments in recent years. They range in scope from private cooperative agreements to international treaties signed by sovereign nations with identified courts of appeal and specified powers of enforcement. Nor is it possible to narrow the scope of the survey by focusing solely on formal treaties signed by sovereign nations. Not only are these few in number - indeed, the financial services provisions of the NAFTA set a precedent, of sorts - but such treaties are not responsible for all (or indeed even most) of the recent advances in this area.

Many of the most important agreements pertaining to international banking and finance have been reached only informally after discussions among a limited number of important nation states or market participants. These agreements have then been enforced using domestic legislation or other means, and have been extended to a wider international community only by force of example. This approach, referred to by Kapstein (1994) as "international cooperation based on home country control", might also be thought the model for further agreements in the area of international finance and banking. However, the relative decline of the industrial countries, amid signs of emergence of a number of new and important financial centres raises questions about who is to participate in future discussions likely to have global implications.

International agreements in the area of banking and finance are the natural by-product of the dismantling of quantitative restrictions on domestic financial markets and international capital flows. They seem to have one of three purposes. First, they may serve to facilitate the conduct of cross-border business. In this category one finds agreements on technical standards, standardised contracts (master agreements), codes of conduct, harmonised accounting and disclosure standards, arrangements for cross-border payment, netting and custodial services, and a wide range of legal 
conventions and agreements governing financial services in general. Second, international agreements may have as one of their objectives the deliberate expansion of cross-border competition in banking and finance. The General Agreement on Trade in Services and the OECD Codes of Liberalisation are examples of agreements in this area, as are the relevant directives in European Union Legislation and the financial services clauses of the FTA and NAFTA. The third purpose of international agreements is to promote or maintain financial stability. Agreements reached by various standing committees which meet at the Bank for International Settlements, under the aegis of the Governors of the Group of Ten, have been particularly important in this regard. The Basle Committee on Banking Supervision is certainly the best known of these committees, while the Euro-currency Standing Committee is certainly the oldest, having been set up in the early 1960s to monitor and assess the implications of the newly established Euro-currency markets. Finally, the Committee on Payment and Settlement Systems has in recent years helped establish policies designed to ensure the continued functioning of such systems even under duress.

Since some way must be found to make this survey manageable, the focus of this paper will be on agreements in this third area. However, it is also worth noting that the strong complementarity between the various objectives distinguished above ensures a more general coverage. For example, harmonised accounting and disclosure standards will help market forces to impose discipline and thus improve financial stability. Assurances about the legal validity of netting arrangements will work in the same direction. Agreements to expand competition must at the same time ensure that the standards required to facilitate cross-border transactions and minimise systemic risk are in place. In sum, distinguishing between agreements according to their primary objective must be seen as an analytical device which is useful but still imperfect.

\section{Trends in banking and finance and the need for international agreements}

In recent years there has been a very sharp expansion in the scale of both gross and net capital flows between developed countries, between developed and emerging economies, and between emerging markets themselves. For example, balance-of-payments statistics indicate that cross-border transactions in bonds and equities for the G-7 (excluding the United Kingdom) rose from less than $10 \%$ of GDP in those countries in 1980 to some $140 \%$ in 1995. Foreign investment in South-East Asia rose to about US\$ 80 billion in 1995. The growing size and scope of international financial 
markets is also evident in the results of a survey of foreign exchange and derivatives markets conducted by twenty-six central banks in April 1995 and coordinated by the BIS (see BIS, 1996b). Daily foreign exchange turnover that month amounted to US\$ 1.2 trillion. In the global derivatives markets, surveyed comprehensively for the first time, average daily turnover amounted to US\$ 900 billion and of these trades more than half were between agents registered in different national jurisdictions. As for outstanding notional amounts of derivative contracts, the survey implied that these amounted to almost US\$ 50 trillion in over-the-counter (OTC) markets alone. ${ }^{1}$ These derivative markets, in addition to being fast-growing, complex and highly interdependent, are also quite highly concentrated. ${ }^{2}$ The kinds of derivative instruments available to allow clients to obtain precisely the combination of risk, return and liquidity desired also continue to expand, as does the number of trading centres where such contracts can be exchanged.

In recent years there have also been significant changes in the nature of the international banking and finance business. In the early 1980s, virtually every OECD country curtailed (or even refused) the right of establishment to some, if not all, foreign financial institutions. However, by the early 1990s virtually all of this discrimination had disappeared; for example, in 1995 there were well over five hundred foreign banks operating in London and over fifty in Canada. Indeed, in the EU, there is now talk of direct access of foreign firms to domestic trading and settlement systems; i.e. participation even without a direct, physical presence. While these trends are most advanced in the wholesale markets of London and New York, similar trends can be seen in both industrial and emerging economies. A growing number of emerging countries now clearly recognise the substantial benefits that foreign banks and other financial institutions can bring in terms of both enhanced competition and technological transfer.

Another important change is that securitisation, fading regulatory barriers and active risk management have served to blur the distinction between commercial and investment banking. Banks

1 The reported number of US\$ 40 trillion has to be grossed up to reflect gaps in reporting. Outstanding exchange-traded contracts were estimated at a further $\$ 16$ trillion, though these estimates have not been adjusted for double counting and, for other reasons, are not strictly comparable to estimates of OTC contracts outstanding.

2 Concerns about the degree of concentration are lessened by the fact that different firms tend to be dominant in different market segments, and that the net price risk exposure of financial institutions in their dealings with nonfinancial institutions in April was quite small. That is, financial institutions' client business seems to be well-balanced. 
are relying more and more on non-interest income to support their profits. In particular, fees for services together with proprietary trading have for many firms become a significant complement to the traditional lending business. At the same time, other financial institutions have entered into the competition for more traditional banking business. Armed with new technology, investment dealers have now begun to offer ways of unbundling risks inherent in bank loans and to price them in the securities markets. Alternative savings instruments to bank deposits are growing rapidly; deposits in mutual funds in the United States are now larger than those in the banking system, although the process of diversifying these assets internationally is only beginning.

In summary, financial transactions are being increasingly conducted on a multi-currency, global level; the distinctions between various kinds of financial institutions and instruments are breaking down; and the intensity of competition between firms continues to increase. Indeed, during 1995, the further reduction in intermediation spreads, particularly for syndicated loans, and a further relaxation of covenants attested clearly to these competitive pressures.

It is important to note the reasons for these developments, because they are fundamental and not likely to be reversed or easily resisted. Indeed, it is not hard to make the case that these pressures will intensify further. ${ }^{3}$ While the catalyst for the growth of international capital flows was the current account imbalances of the 1970s (including those associated with the OPEC shocks), subsequent developments have been driven in large part by ongoing technological advances and reductions in communications costs which are much more likely to accelerate than stabilise. A very similar set of forces has also contributed to the expansion of trade in goods and services in recent years. The fact that certain kinds of financial transactions have become both possible and costefficient has been a powerful engine feeding growth in demand for these products.

Deregulation of the domestic financial sector in both developed and emerging countries has also played an important role in supporting these developments. In large part, this has been a deliberate attempt to reap the efficiency gains of more open, liberalised financial markets. As discussed in Section 3 below, this is also the primary motivation for wishing to encourage the opening of domestic financial markets to international influences as well. However, in some instances

3 See Andersen, Palle and William R. White (1996). 
deregulation has also been a response to the reality that previous regulations were being circumvented by technology in various ways. Unauthorised operations were simply being carried out offshore, with foreigners getting the business. Viewed from the perspective of either what is desirable, or what is feasible, re-regulation of domestic financial markets would not seem to be the preferred solution to any new problems posed by internationally integrated financial markets.

What is crucial is that private market participants, and those charged with public sector oversight, should both recognise the reality of globalised financial markets and establish international agreements to further both private and public goals. Domestic provisions are no longer adequate because they ignore international competition; i.e. they do not address the joint issues of "level playing fields" and "regulatory competition". Fortunately, there has been an emphasis on international agreements over the last few years, though the leadership of these initiatives has varied depending on the particular need being addressed. Agreements to facilitate the conduct of cross-border financial transactions have in large measure been driven by private sector agents. Conversely, agreements to deliberately encourage the expansion of cross-border competition and to promote and maintain financial stability have been led by the public sector. Given that the former set of agreements directly responds to self interest, whereas the latter two recognise significant economic externalities, this difference in leadership is perhaps not surprising.

What should also be emphasised is that, in virtually all areas where international agreements have been reached, the joint interests of the private and public sectors have somehow had to be taken into account. Arrangements to facilitate (private) cross-border business take place within the framework of domestic (public) legal systems. Conscious efforts to expand international competition must recognise the transitional costs that may be imposed on domestic financial institutions. And measures to ensure systemic stability must not do so at the price of excessively constraining competition in the private sector. The upshot of this is that achieving an international agreement generally demands widespread and arduous discussions among a wide range of private and public sector participants, both within nation states and between them. A further implication is that the process which guides these deliberations may prove crucial to whether they are successful or not. That is why some emphasis is put in this paper on the issues of both process and substance, as we search for ways to move forward in a rapidly changing world. 


\section{Agreements to facilitate the conduct of cross-border business}

International agreements, largely among private sector participants, have provided the basic infrastructure which allows the international financial system to function on a day-to-day basis. Like "plumbing", such agreements are not often the subject of intellectual conversation. We simply assume the plumbing will work. It is nevertheless important to take note of the important aspects of this financial infrastructure as a prelude to assessing international agreements to foster financial stability.

Perhaps the most important, if also most banal, set of agreements in the area of crossborder finance has to do with agreed technical standards that allow the electronic exchange of messages. SWIFT, ${ }^{4}$ under the umbrella of the International Standards Organisation (ISO), has developed accepted standards for this in the banking industry and has established various message categories including interbank funds transfers, foreign exchange transactions and securities trades. As well, there currently exists a set of standards that allows the global operation of various schemes for retail fund transfers. Currently, a great deal of attention is being directed to technical issues having to do with the use of the Internet for financial transactions and possible standards for the use of pre-paid stored value cards ("smart cards" as opposed to electronic funds transfer). To come into effect still further in the future, worldwide message standards are being developed under the auspices of the United Nations (UN/EDIFACT) with a view to allowing worldwide exchange of data across a variety of business sectors, regardless of the language of origin or the communications and computer systems employed. What the implications of the more developed, general standards will be for wellfunctioning industry standards (for example, SWIFT in banking and RINET in the reinsurance industry) remains to be seen.

Another set of international agreements, primarily developed in the private sector, are codes of conduct ${ }^{5}$ established by members of various trade associations. ${ }^{6}$ These codes commonly

4 SWIFT, the Society for Worldwide Interbank Financial Telecommunications, is a commercial organisation set up in 1973 and is maintained by financial organisations throughout the world. Relations between SWIFT and SWIFT users are governed by contractual arrangements. Since SWIFT rules are incorporated into interbank contracts, the influence of SWIFT on the harmonisation of such contracts has been substantial. See Heinrich, Gregor (1996).

5 For a recent example of the genre see Federal Reserve Bank of New York (1995), Principles and Practices for Wholesale Financial Market Transactions. Representatives of the Emerging Markets Traders Association, the Foreign Exchange Committee of the Federal Reserve Bank of New York, the International Swaps and Derivatives Association, the New York Clearing House Association, the Public Securities Association and the Securities Industry Association participated in the preparation of the Principles. The preparation of the Principles was coordinated by the Federal Reserve Bank of New York. 
define "best practice" in such areas as the financial resources of participants (their adequacy to support the risks being borne), policies and procedures related to transactions (control and compliance, valuation procedures, etc.), relationships among participants (fair dealing, ${ }^{7}$ etc.), the mechanics of transactions (documentation, settlements of differences, etc.) and acceptable standards (manipulation, bribes, rumours, etc.). These codes of conduct are voluntary and, as such, have no legal authority. Nevertheless, they establish a set of standards by which participants will be judged in the market place, potentially to their significant cost. The official sector is often involved in an informal way in meetings of market participants designed to review recent developments in this area. For example, the New York Foreign Exchange Committee, which published at the end of 1994 a code of best practices for foreign exchange settlements, was initially "sponsored" by the New York Federal Reserve Bank. Closer to my home, the Secretary for the meetings of the Canadian FOREX group is a senior official of the Bank of Canada. This involvement of officials may further encourage good behaviour if it is feared that official sanction of bad behaviour could be applied in some other way.

Another area where the private sector has been the leading agent for change is in that of harmonised accounting and disclosure standards. Any financial transaction involves a degree of credit risk and it is therefore important that counterparties should be able to make a reasonable assessment of how great that risk is. A complication with respect to international transactions is that the accounting standards used by the counterparty may differ from home country standards. For example, the Anglo-American approach to the accounts of financial institutions stresses the shareholders' interests and tends to emphasise market values. In contrast, European accounts emphasise more the interests of creditors and rely more on book values. ${ }^{8}$ Such differences have led in recent years to efforts to harmonise international accounting standards for financial institutions, with the ancillary purposes of increasing transparency and moving more systematically towards mark-tomarket accounting.

6 Perhaps the most important of these are the agreements reached by ISMA, ACI, ISDA, PSA, LBMA and the Group of Thirty.

7 This aspect of good conduct has received a great deal of attention in the last year or two. A number of derivative dealers in the United States have been sued for allegedly recommending to clients transactions which were inherently so complicated that the client could not reasonably be expected to fully understand the associated risks.

8 It is also contended that the Anglo-American approach focuses on the substance of financial transactions, whereas the European approach puts more emphasis on the legal form of what is taking place. 
At the moment, two possible outcomes seem most likely. One possibility is the globalisation of the Generally Accepted Accounting Principles (GAAP) used in the United States. This standard derives its principal advantage from being used in what is still the world's predominant financial centre. Its disadvantages include being excessively detailed, too US orientated, highly complex and thus hard to explain. The main alternative to the GAAP are the International Accounting Standards (IAS), drawn up by the International Accounting Standards Committee (IASC), ${ }^{9}$ whose provisions reflect the thinking of accountants from a much wider range of countries (in particular, the United Kingdom, France, Germany, Canada and Australia as well as the United States). The IAS received some significant support in 1995 as the International Organization of Securities Commissions (IOSCO) effectively accepted the IAS's existing standards as a basis for their work programme and for use in multinational securities offerings and other international offerings. In addition, during 1995 the European Union gave up its search for Europe-wide accounting standards, and pointed member states in the direction of the IAS. While there can be no final resolution of this issue without the agreement of the US Securities Exchange Commission in the United States, this agency has been making some more accommodative statements of late.

Other largely private and non-binding initiatives have had to do with encouraging disclosure of firm-specific information, complementary to that contained in audited accounts. The focus of attention here has been on the treatment of derivatives and other off-balance-sheet items. Among the first group to consider this was the Group of Thirty (1993) who, after surveying fifty-eight major market participants worldwide, recommended disclosure of replacement value of derivatives, activity levels based on nominal values, and qualitative disclosure regarding how derivatives were being integrated into the firms' overall risk management procedures. These recommendations, which were primarily addressed to an assessment of credit or counterparty risk, were subsequently endorsed by the Institute of International Finance (1994) and now seem likely to become standard practice on a global basis. The IIF discussed recommendations having to do with the disclosure of market risk exposure but were unable to obtain sufficient agreement from industry participants.

9 The IASC is an independent private sector body, whose members include all the professional accounting bodies in the International Federation of Accountants (116 member bodies in 85 countries). 
More recently, the public sector has also begun to encourage greater disclosure of both credit risk and market risk associated with trading activities in general, and off-balance-sheet items in particular. Public sector involvement reflected the recognition that such trading might pose certain systemic risks, but it was also a response to the fact that there was a hesitancy on the part of individual private sector firms to be the first to disclose relevant information. Accordingly, in late 1994 the Fisher Committee, a sub-committee set up by the Euro-currency Standing Committee at the BIS, issued a report, ${ }^{10}$ urging not only greater disclosure of credit and market risk, but also an ex-post assessment of how well risks had been managed. Around the same time, the Basle Committee on Banking Supervision made a similar recommendation (in association with IOSCO; see BIS: Basle Committee on Banking Supervision, 1995c). Moreover, over the last year, systematic efforts have been made to monitor annual reports and other publications to see how firms have responded; in November 1995 the Basle Committee and IOSCO released (BIS: Basle Committee on Banking Supervision, 1995e), an assessment of progress to date. The general response of the industry has been very positive, ${ }^{11}$ although some firms are clearly further ahead than others in being able to assess exposures and communicate their risk management performance. It looks increasingly as if the market dynamic envisaged by those wishing to encourage greater disclosure is coming into play. Once a few large firms have been induced to "disclose", other firms must go along for fear of being accused of having something to hide. This new information then proves useful in assessing counterparty risk and minimising reactions based on poor information that could lead to systemic problems. This general issue is returned to in Section 5 below.

It has also been long recognised by market participants that international transactions have a special risk attached to them, namely; uncertainty as to which set of national laws may apply under different circumstances, including that of the bankruptcy of one of the counterparties. One attempted solution, which falls short of formally harmonising the laws themselves, has been for the private sector to try to agree on harmonised contract clauses. This also has the advantage of reducing the capacity of market agents to "shop around" for rules which suit them best. By choosing a common

10 See BIS: ECSC (1994a).

11 For an assessment of how disclosure fits into a broader strategy to minimise systemic risk, see White, William R. (1994b). 
set of contractual clauses, partners to a financial contract can reduce potential legal conflicts by agreeing in advance to apply common principles. In the past it has been common for trade organisations, operating either nationally or internationally, to champion the use of such standardised contracts and a large number of these are now in common use.

If the private sector has played the leading role in most of the agreements cited above, there are other areas where the role of the state has been more preponderant. This is particularly the case where efforts have been made to harmonise statutory rules internationally, as a more fundamental means of avoiding uncertainty about jurisdictional issues. On the one hand, such harmonisation can be achieved through states agreeing to International Conventions committing themselves to incorporate specific rules into national legislation. Examples of such conventions having implications for the international financial sector are the Geneva Conventions (Cheques and Bills of Exchange) and United Nations Sales Conventions. However, it must be admitted that this "convention" route has not proved an easy one to follow in recent decades. Thus, an increasingly favoured approach is to foster harmonisation through "model laws" or "model statutory provisions" which are only suggested for adoption by national legislators. These model rules are today prepared almost exclusively by permanent bodies or international organisations entrusted with the task. ${ }^{12}$ It must be admitted, however, that this alternative approach has also failed to meet with much success.

An interesting initiative in this area is the United Nations Commission on International Trade Law (UNCITRAL) model law on international credit transfers, which attempts to provide a comprehensive body of rules to govern relations between participating parties. Since the model law parallels in certain respects US legislation, and since the Commission of the European Union is using the model law as the basis for its own thinking, prospects for more general harmonisation - at least in some aspects of funds transfers - look relatively good. A good example of the harmonisation of rules in the financial sector is the introduction of Article 4-A on electronic funds transfers in the US Uniform Commercial Code. However, this effort is aimed at harmonising national rules, i.e. the laws

12 For a full description of initiatives in this area, see Heinrich, Gregor (1996). Private sector institutions so engaged are industry trade groups, the International Chamber of Commerce, the International Law Association and the Council on International Banking. Heinrich notes there are thirty international organisations working on the harmonisation of trade law more generally, with the Hague Conference, the United Nations (UNCITRAL), the European Union, the Council of Europe and UNIDROIT being the best known. 
of the US federal states, which is not the same thing as an international agreement. Within the European Union, EC Directives may have a more drastic effect, since they may force national governments to alter their specific national laws with a view to European harmonisation. Conversely, it must be noted that a number of other initiatives to harmonise international legislation have not succeeded. Perhaps the best example would be the ongoing difficulties in harmonising bankruptcy laws in the major states of the European Union, in spite of efforts extending over some years.

The backbone of financial markets consists of a complex and often overlooked infrastructure including trading systems (exchanges, OTC arrangements), custody services and payment, clearing, netting and settlement systems. Many new systems have been set up in recent years; for instance, exchanges for trading in options and futures and their respective clearing organisations. Moreover, many other traditional (domestic) arrangements have undergone significant changes in recent years in order to cope with the increasing volume of international transactions in many financial markets. At the same time, new, complex and truly global infrastructures have been created in many different areas of the financial industry: global financial information services such as Reuters, which underpin trading in the foreign exchange and international securities markets; multinational credit card companies, such as Visa and Mastercard; specialised settlement services for international or cross-border securities transactions offered by the international central securities depositories, Cedel and Euroclear, and by global custodians; linkages between domestic central securities depositories, between domestic ACHs (Automated Clearing Houses), and between domestic derivatives exchanges; multi-currency and cross-border netting schemes for foreign exchange contracts based on bilateral and, most recently also, on multilateral procedures. This is complemented by the traditional but ever-evolving multinational web of banks and other institutions, which are linked by a series of communication networks operated by the financial institutions themselves, by telecommunication companies or by specialised suppliers. In 1994, for instance, SWIFT conveyed 518 million messages between almost 5,000 users in over 130 countries.

\section{Agreements to extend cross-border competition}

It is striking how much progress has been made in recent decades in liberalising merchandise trade. Yet, the most dynamic component of trade has not been goods but rather services, in particular financial services. Even though under-recorded, services currently account for over one-third of 
measured trade. Nevertheless, multilateral trade liberalisation in the services sector has lagged the merchandise sector by a very wide margin. Only during the latest round of multilateral trade negotiations (the Uruguay Round) did services become an integral element of the trade liberalisation efforts.

A possible reason for the relative neglect of services in international agreements is that cross-border competition in services does not only take place through cross-border trading. Market access can also be gained through firms establishing residence in the jurisdiction in which they offer their services. A large proportion of the many agreements described in the preceding section are designed to facilitate the former kind of competition in the provision of financial services. In contrast, there exists a much more limited number of international agreements among sovereign states which are directed to enhancing both forms of competition. These agreements are treated chronologically below, with some emphasis placed on potential conflicts arising from bilateral and regional agreements having to do with the cross-border provision of financial services.

Unquestionably, the most important multilateral agreements affecting international trade in this area have been the OECD Codes of Liberalisation of Capital Movements and of Current Invisible Operations. These codes provide for the progressive liberalisation of capital flows and the provision of financial services on the basis of "national treatment", and they have been successively revised and updated since their promulgation in December 1961. Whether due to these codes or to the other influences noted in Section 2 above, OECD members have (in spite of the absence of enforcement mechanisms) drastically altered national legislation in recent years to comply with the spirit of the codes. In this regard:

"Claiming that the developments since the mid 1980s have been significant would be an understatement: we are in a different world. Most striking is the fact that all member countries have lifted most or all of their intentional restrictions on foreign establishment. With a few exceptions (foreign firms) are legally free to offer the same range of services as domestic firms. Not less important has been the general repeal of foreign exchange rate controls throughout the OECD area." 13

13 See Organisation for Economic Co-operation and Development (1993), p. 22. 
The broad scope of the liberalisation commitments in the OECD codes can also be demonstrated in a more negative way by noting the difficulties which Korea is currently experiencing in gaining membership to the OECD.

The Free Trade Agreement signed by the United States and Canada in 1989 was the first attempt to develop formal rules and disciplines for financial services in a trade policy setting. In this conceptual sense it was revolutionary, but in practical terms it was less so. The Agreement addressed some long-standing grievances about "access" within the Canadian and US markets, but it did not do so on the basis of any well-articulated and forward-looking ${ }^{14}$ set of principles. Moreover, in the aftermath of the treaty, very little of consequence happened. Far from coming to dominate the Canadian financial scene, US financial institutions generally lost market share and a number of them withdrew from the Canadian market entirely.

In contrast, the North American Free Trade Agreement was based on a forward-looking set of principles designed more to enhance access than to simply preserve it. The search for principles was in part due to the desire to extend the NAFTA over time; transparent principles would ease such an extension. Beyond this, the US, Canadian and Mexican participants all hoped that these principles might serve as a model for trade agreements in other fora. Most importantly, at the time NAFTA was being negotiated, the future shape of the General Agreements on Trade in Services (GATS), and in particular financial services, was still to be determined. Moreover, it was felt that successful implementation of a principles-based agreement, to which an important emerging economy was party, might provide an important precedent for regional trade agreements elsewhere. If so, shared principles underlying such regional arrangements might lessen the danger that they could get in the way of forging more global agreements. ${ }^{15}$

The broadest principle of all in the NAFTA recognises that all firms providing financial services should have equal access to all customers in all participant countries, either through cross-

14 The only guiding principle, in addition to that of national treatment, was to preserve "the access that our respective financial institutions have to each other's markets". See Canada: Department of External Affairs (1987), p. 249.

15 There were also less altruistic reasons for the Canadian and US governments to pursue this principles-based approach. Canada feared that, without clear principles in place, the United States would use regulatory change to the disadvantage of Canadian financial institutions. The US administration apparently felt much the same about the Mexican Government, and wished as well to anchor trade liberalising principles in a legally binding treaty so as to condition future domestic legislation. See White, William R. (1994a), p. 12. 
border trading or rights of establishment, and that there should be no discriminatory legislation. The treaty also emphasises the need for transparency in all government decisions in this area; the need to recognise that national treatment must be de facto and not just de jure; ${ }^{16}$ and it lays down specific procedures for dispute resolution.

The treaty also lays out certain provisions with respect to supervision. Most importantly, supervision will continue to be host rather than home-based, though regulators can negotiate bilateral agreements providing for regulatory or supervisory harmonisation. While NAFTA left in place the existing differences between the structures of the Canadian/Mexican and US banking systems (differences related primarily to multi-branching and universal banking), its principles explicitly espouse universal banking, multi-state branch banking and international branch banking. The upshot is that the repeal by the United States of the McFadden and Glass Steagall Acts, would oblige Canada and Mexico to alter domestic legislation to bring these principles fully into play. In this altered world, it would not be inconceivable for the harmonisation of regulations to proceed a very long way. Should this happen, it would also be more likely that host supervisors would come to rely more heavily on input from home supervisors. This would also be helpful for global developments since, as will be discussed below, a home-based approach to supervision is more or less the norm elsewhere in the world.

Not a great deal needs to be said about the European Communities Second Banking and Investment Services Directives, even though they are significantly more ambitious than the corresponding parts of NAFTA. The directives provide free right of establishment in member countries, a liberalised regime for the provision of cross-border services, and a harmonisation of essential rules across countries. The right to establishment throughout the community requires only a single licence ("passport"), a feature which also applies to subsidiaries of firms from outside Europe. ${ }^{17}$ As for supervision, the directives lay out the principles of home country regulation and mutual recognition by EC members of each other's regulatory regimes. The Directives also stipulate certain capital adequacy standards for financial institutions as well as disclosure rules. Some of the

\footnotetext{
16 It is now widely recognised that an absolutely identical application of regulations may disadvantage foreign firms. See OECD (1993), p. 4. De facto national treatment is sometimes referred to as "reciprocity in the sense of equal competitive opportunities" as opposed to "mirror image reciprocity".

17 Note that the single passport does not apply to branches of non-EU firms, only subsidiaries.
} 
complications which have emerged in this area, given the existence of capital adequacy rules laid down under the aegis of the Basle Committee on Banking Supervision (essentially a G-10 grouping) are discussed further below.

The most recent international agreement in the area of banking and finance was the Financial Services Agreement (FSA) signed by seventy-six countries at the World Trade Organization in July 1995. ${ }^{18}$ This agreement is a sub-agreement to the General Agreement on Trade in Services which, in that it dealt with services, was one of the major achievements of the Uruguay Round. The FSA is based on the traditional principles of Most Favored Nation and national treatment, and entailed a large number of countries offering binding commitments having to do with specific areas of financial services. The effect will be to ease cross-border establishment problems, as well as the provision of services across borders by non-established firms, particularly in emerging markets where the OECD codes have not thus far been widely applied.

After two full years of negotiations, the United States announced in June 1995 that it was dissatisfied with the liberalisation commitments offered by a number of (mostly Asian and Latin American) countries. Under those circumstances, the United States withdrew its previous offers on financial services and decided not to accept the MFN principle with regard to financial services. Foreign institutions already active in the United States, however, would be grandfathered. Given the competitive potential for US financial firms to expand abroad, this decision was understandable if still regrettable, as this country had up until that time applied an unconditional national treatment standard to foreign firms. The other countries that accepted the agreement have committed themselves to implement their liberalisation offers before November 1997, when it is very much hoped that renewed negotiations will lead to the United States being able to participate more fully. ${ }^{19}$ The US authorities have still more recently taken a similar, tough stand at the WTO with respect to telecommunications.

There were also extended discussions, in the context of the FSA negotiations, about the need for adequate prudential regulation of those providing banking and insurance services. However, in the end, no agreements were reached and the final text includes only a statement of principle to that

\footnotetext{
18 See World Trade Organization (1995a).

19 See World Trade Organization (1995b).
} 
effect. Similar to the decision taken earlier to leave questions of exchange rate adjustment to other fora than the World Trade Organization, it was perhaps implicitly recognised that issues having to do with regulation and supervision might also be better dealt with elsewhere. Increased international competition is clearly an important objective, but it must still be weighed against the other important goals of macroeconomic and systemic stability.

\section{Agreements to promote and maintain financial stability}

Before turning to some specific international agreements directed towards the goal of financial stability, it is useful to review the need for such agreements and the processes which have been followed to achieve them in practice. International financial crises have in fact played too important a role in catalysing change over the last thirty years. This leads directly to the question of whether better and more forward-looking procedures can be devised. While a good case can be made that this has begun to happen over the last few years, this paper concludes (Section 5) with identification of some areas where further progress is needed with respect to matters of both process and substance.

\subsection{The purpose of international agreements}

Domestic deregulation and technological advances have increased the scope for risk-taking on the part of market participants. New instruments and globalisation of markets have increased the complexity of deals and substantially reduced transparency. Moreover, the volume of transactions has grown enormously as have the associated payment and settlement requirements. Profits of financial institutions have come under increasing pressure and there has been a long-standing tendency to respond to lower rates of return on capital by taking on still more risk. This is arguably the dynamic which led to "bad loans" to LDCs ${ }^{20}$ being replaced by loans for leveraged buy-outs, then loans for acquisition of property, and finally proprietary trading in complex derivative instruments in recent years. Since these competitive pressures seem likely to grow further, it can be concluded that the potential for financial instability has grown and could grow further. ${ }^{21}$

20 For the sake of balance, it should be noted that the official sector played an important role in inducing banks to expand their lending to developing countries in the wake of the two oil shocks of the 1970s and the "need for recycling". Kapstein (1994) provides an interesting assessment of this.

21 See Chapters V and VII of the 66th Annual Report of the Bank for International Settlements (1996c); see also Folkerts-Landau, David and Takatoshi Ito (1995). 
If international competition is one part of the problem, a recognition of this fact must also condition potential solutions. Individual countries cannot regulate or supervise their domestic institutions and markets without recognising the implications for international competitiveness. In the United States, for example, efforts to force banks to hold more capital in the early 1980s (in light of the Mexican crisis) led to stiff industry resistance on competitive grounds and led directly to strengthened efforts within the Basle Committee on Banking Supervision to come up with an international agreement. Moreover, agreements reached at the international level must also be sufficiently comprehensive in terms of the countries they cover, that they do not open up the possibility of regulatory competition with non-participating countries. This could easily lead to a competition in regulatory laxity ("regulatory arbitrage") from which no-one would benefit.

The purpose of international agreements directed to enhancing financial stability is not to prevent bankruptcies of individual firms. Any set of agreements that ensured this would surely be unduly constraining competition at the same time. Rather, the purpose is to ensure that the financial system as a whole is resilient enough so that it will continue to function well, without macroeconomic side-effects, regardless of the shocks to which it might be subjected. In sum, the objective is to avoid systemic failures of the sort seen frequently in history, and most recently during the Great Depression. Given the extent to which financial markets are now global and interlinked, the conclusion that systemic problems might now be even more endemic might seem obvious. In fact, this may not be the case, since interlinked markets could just as easily serve to dissipate shocks as to exacerbate them. Yet, from a prudential perspective, it is clearly better to plan for the worst and hope for the best than to follow the opposite course.

\subsection{The process of achieving agreement}

For representatives of sovereign governments to reach international agreement in this area is not an easy task. Banking and finance, along with energy, telecommunications and agriculture, have long been considered by governments and citizens as being especially sensitive. Moreover, different governments have different priorities for change, different levels of concern about the seriousness of systemic problems, and different interests on the part of the domestic financial communities they must represent. With respect to the last issue, each country starts off with different traditions, accounting systems and domestic regulations, and the desire is always to minimise for domestic firms the extent 
and costs of any changes arising from the international agreement. The fact that significant progress has, nevertheless, been achieved, raises the question of the conditions which favour such agreements. Kapstein (1992) identifies three things: a shared recognition of a common problem, some agreement on how the financial system should function and how problems might be best addressed, and the continuing exercise of state power to make it happen. The first two conditions seem to be being met in increasing measure, though not necessarily the third.

Perhaps the first example of shared recognition of a common problem had to do with the growth of the Euro-currency markets in the early 1960s, a product of the Cold War, rising dollar assets abroad and the desire to evade US reserve requirements. Concerns were raised at the time about the dangers to international financial stability posed by markets thought to allow uncontrolled growth in money and credit. This led the G-10 Governors, in 1962, to establish the Euro-currency Standing Committee which was given a mandate to monitor and assess developments in these international markets. This committee has continued to meet regularly at the BIS ever since, even though its initial deliberations concluded there was no need for an internationally agreed response to these particular developments. Subsequently, various issues have arisen which have also been recognised as being of interest and having an international dimension; for example, the need for supervision of international banks and mechanisms for providing them with liquidity support, the growth of international payments systems, and the extension of derivatives markets. However, in the following two decades or more, it would have to be said that common problems subsequently came to be recognised as such only in the context of some international crisis; this is referred to further below.

As for some shared recognition of how the financial system should function, and how public policy might help reduce systemic risks, significant progress has been made in recent years. Central banks and regulators have conducted extensive research over the years, as have universities and various international organisations; in particular, the BIS, IMF and the OECD. Moreover, this research has been carried out in close cooperation with private sector participants in financial markets to ensure a shared data base of practical experiences. As a result, and also as a consequence of regular meetings over many years, a community of central bankers and regulators has emerged whose shared values may give them more in common than they may have with various parts of their national governments. This has a clear advantage in obtaining results. However, it also has dangers in that it 
can lead to public concerns about the existence of "a democratic deficit"; that is, important international decisions being made by technocrats rather than politicians. ${ }^{22}$

One particular way in which this last problem has been addressed is by basing international cooperation firmly on home country (state) control, rather than entrusting it to some international institution. The various committees which meet under the aegis of the G-10 Governors, or Ministers and Governors, negotiate among themselves, each recognising national objectives, and attempt to find a mutually acceptable way forward. Policy recommendations are then ratified by Ministers and Governors and are applied at the national level using national law or regulation if required. The fact that national legislators generally go along with this, as do the private sector participants whose business is directly affected, testifies to the moral authority exercised by these international agreements and the perceived legitimacy of the process which closely involves all domestic parties likely to be affected. To date, many of these agreements have simply been accepted by non-G-10 countries as "global standards". This latter process has been aided by the efforts of various committees at the BIS, but particularly the Basle Committee on Banking Supervision, to reach out to regional groups, and by the efforts of the IMF and other international institutions to inform authorities in emerging economies about these agreements.

This is not to imply that the process of achieving international agreements directed to systemic stability has always been smooth. It has not. All too frequently a problem has been identified, but it has taken a crisis to move the agreement process forward. For example, the Basle Committee was set up in the wake of the failure of the Bankhaus Herstatt even though it had been recognised for some time that banks with large international operations posed special problems. Concrete work on forging international capital adequacy standards began only in the wake of the Mexican crisis of 1982. Finally, but by no means exhaustively, the G-10 Committee on Payment and Settlement Systems was set up in 1989 following various periods of financial distress with crossborder repercussions, including the 1987 stock market crash and the failure of Drexel-BurnhamLambert.

22 Concerns of this sort have frequently been raised in the context of the European Community, and it would not be surprising for US Congressmen to be even more concerned. 
It is also noteworthy that, at various times, more powerful members of the Group of Ten have forced the process in rather unconventional ways. For example, in the mid-1980s progress in harmonising different approaches to capital adequacy standards was deemed "too slow" by the US authorities. Accordingly, the United States and the United Kingdom, representing the two largest financial centres by far, struck a bilateral deal (based in fact on the UK approach to risk-weighted capital standards) which led others to worry that their banks might lose access to US and UK financial markets. This led to a sharp increase in the intensity of negotiations in Basle which eventually led to agreement on the Capital Accord, on terms which, it should be stressed, were satisfactory to all the major participants. Finally, it should be noted that the process has on occasion moved forward extremely slowly. Herstatt risk was identified and so named in 1974, yet the first significant set of public sector initiatives to deal with it were promulgated by the Committee on Payment and Settlement Systems only at the end of March 1996.

Whatever success has been achieved has been materially aided by having a relatively small number of countries participating in the negotiations, and by recognising the continuing leadership of the United States and to a lesser degree the United Kingdom. However, a number of developments could complicate this formula in the future. First, the liberalisation of economic systems around the world is leading to a much greater dispersion of wealth and influence, and a decline in the relative position of the Group of Ten in general and the United States in particular. This is likely to lead many emerging countries to desire to have a bigger voice in issues that affect them. Second, many emerging countries already have domestic financial systems of such a size that systemic problems locally could have important systemic effects internationally. ${ }^{23}$ This implies that the industrial countries might wish to profit from their input as to how the financial world might be made safer. Third, a united Europe, speaking with one negotiating voice, is likely to have a different attitude to the United States than a number of countries speaking separately.

\subsection{Specific agreements to foster financial stability}

Agreements to foster financial stability can generally be classified as directed to prevention, and/or crisis management and resolution. This paper will deal with agreed measures to deal with problems

\footnotetext{
23 This point is one of the principal conclusions of the recent report of the G-10 Deputies on resolving sovereign
} liquidity crises. See Group of Ten (1996). 
arising in the financial system itself, and will eschew all reference to measures (which can be similarly classified) to avoid sovereign liquidity or debt crises. ${ }^{24}$

\section{Prevention}

A useful framework for classifying measures to prevent systemic crises is a four dimensional matrix based on the flow of funds. ${ }^{25}$ The various columns comprise the activities of the various economic agents, with the most important for our purposes being: the banks, investment dealers, insurance companies and other financial institutions. The rows are the markets for the individual instruments (assets and liabilities), some of which (a declining proportion) are nontradable. Behind this facade is a third dimension comprising the supporting infrastructure for the international financial system: the legal system, payments systems and other components described in Section 2 above. Finally, the fourth dimension is the set of market-clearing conditions which binds these interlinked markets together. Failures at the level of the first three dimensions could have implications for market-clearing conditions that would be large enough to have serious macroeconomic implications. Indeed, it is conceivable that the markets themselves could generate a set of prices that could have similar macroeconomic effects. Examples might be dynamic hedging strategies that led to large, cumulative price movements, or "bubbles" that burst with significant effects on the capital of financial institutions. ${ }^{26}$

Over the years a number of international agreements have been reached to strengthen the first three dimensions of this matrix. Much of this work, although certainly not all, has been carried out by three permanent committees reporting to the G-10 Governors at the BIS; each effectively responsible for one dimension. ${ }^{27}$ This broad-based approach to containing systemic crises might seem to contrast unfavourably with a strategy of identifying precisely how a crisis might get started and then taking steps to ensure it could not happen. The problem with this latter approach is that such

24 See Group of Ten (1996); see also Eichengreen and Portes (1995) for a detailed bibliography.

25 This framework was first suggested in White, William R. (1994b).

26 Some initial consideration of the possibilities arising from the increased use of derivative instruments is given in Hannoun (BIS: ECSC, 1994b). For a more recent analysis of trends in volatility in financial markets see BIS (1996a).

27 The last chapter of the Annual Report of the BIS provides a detailed review of the work of each committee in the year in question. See, for example, the BIS 64th and 65th Annual Reports. 
an identification is beyond our capacities. Crises are just as likely to result from the unpredictable interactions between a number of very minor events as to arise from some single cause; a "chaotic" outcome in effect. While this reasoning might seem fanciful to some, it is an interesting historical fact that the Banco Ambrosiano failed in 1982 only a month before Mexico announced it could no longer service its external debts. Had financial markets been as well developed then as they are today, the final effects of these near-joint events might well have been different. Some commentators have also speculated on what might have happened if, at the time of foreign exchange turmoil at the end of 1993, when turnover in financial markets increased drastically, systems such as SWIFT or Reuters had failed.

The Basle Committee on Banking Supervision was created in 1974 (then named the Committee on Banking Regulations and Supervisory Practices) and has been the source of many agreements directed to strengthen supervision of the international banking system. The first agreement of this sort was the Basle Concordat (BIS: Basle Committee on Banking Supervision, 1975), which established the principles that no foreign banking establishment should escape supervision, and that supervision should be adequate. In light of changing circumstances and perceived shortcomings, the Concordat has been revised a number of times, most recently in light of the failure of the Bank for Credit and Commerce International, but the key point which remains is that the home or parent supervisor should supervise the global operations of his group using consolidated data to the degree possible.

The Minimum Standards paper of 1992 (BIS: Basle Committee on Banking Supervision, 1992) laid out four standards designed to ensure that home supervisors do practise effective consolidated supervision (if not, the host country can refuse a banking licence) and to ensure that the home supervisor has access to adequate data about cross-border activities (if not, the home supervisor could refuse to allow this business to continue). Nevertheless, the Supervisors feel there is still room for further measures to facilitate the flow of information between host and home supervisors, and to this end prepared a paper for discussion at the biennial conference of all the world's supervisors in Stockholm in June of this year. ${ }^{28}$ One area of concern is to tighten the confidentiality constraints to

28 See Report by a Working Group comprised of Members of the Basle Committee on Banking Supervision and the Offshore supervisors Group (BIS: Basle Committee on Banking Supervision, 1996a). 
which a recipient is subject so that senders need not fear that supervisory information will get into the public domain. Another area of concern is that some countries (like Switzerland and Singapore) do not allow on-site inspection by home country supervisors. This would demand legislative changes in the countries concerned, which may prove very hard to achieve. It should also be noted that the general principles laid down by the committee have frequently been supplemented by bilateral Memoranda of Understanding. Most European supervisors have already done this ${ }^{29}$ and the United States and the United Kingdom are just about to do so.

Another important achievement of the Committee was the promulgation of the Basle Capital Accord which was finalised in 1988 and laid down capital adequacy requirements for internationally-active banks based on relative levels of exposure to various forms of credit risk. While still subject to many criticisms, the Accord did suffice to level the international playing field, particularly with respect to Japanese competition, and also led to a significant strengthening of bank capital after a long period of slow deterioration. Moreover, the Accord also addressed off-balancesheet risk, which was another progressive step. By September 1993 all the G-10 banks with significant international operations were in fact meeting, and many were exceeding, the minimum requirements of the Accord. Since the Committee has no powers of compulsion, this success rate was due to a combination of pressure from domestic supervisors (obviously operating under international peer pressure) and market discipline. This latter influence could be more easily imposed given the clear quantitative standard in the Accord and its universal acceptance as a standard by rating agencies. The Accord has been periodically revised; for example to define the rules regarding netting (BIS: Basle Committee on Banking Supervision, 1996b). The biggest advance, however, has been the very recent extension of capital requirements to market risk in which the Committee accepted the use of internal (firm specific) "market value-at-risk" for supervisory purposes, subject to certain prior conditions being met (BIS: Basle Committee on Banking Supervision, 1995a, 1995b).

The acceptance of the use of internal models has been a major step forward for the Basle Committee, as has its increased espousal of disclosure as a means of enlisting market discipline to

29 In the European Union, central banks and other banking supervisors coordinate the oversight of all direct participants in payment systems, including the exchange of information necessary to exercise this oversight. 
complement the more traditional approach to regulation (see Section 2 above). In making its recommendations about both disclosure and guidelines for risk management practices, the Basle Committee worked closely with the Technical Committee of IOSCO (BIS: Basle Committee on Banking Supervision, 1995c). Another recent example of supervisory cooperation was the publication of a paper on the supervision of financial conglomerates (BIS: Basle Committee on Banking Supervision, 1995d). Recognising the growing influence of such conglomerates in the provision of international financial services, the Basle Committee, together with IOSCO and the International Association of Insurance Supervisors, have agreed to set up a Joint Forum to discuss these matters further. Early attention is likely to be paid to the controversial suggestion of an "identified lead regulator" for each conglomerate of significant size.

If the supervisors oversee the columns of the systemic risk matrix referred to above, the Euro-currency Standing Committee, which also reports to the G-10 Governors, is concerned with the rows. Since its foundation in 1962, the Committee has regularly discussed financial market developments thought likely to have systemic implications. In the early days, the focus was almost entirely on international banking, in particular the implications of the explosion of interbank debt, but that focus has now widened significantly in recognition of the major structural changes which have taken place in the financial industry. The Committee's first report on derivative instruments (BIS: ECSC, 1986) was published in 1986. In autumn of 1994, the Committee submitted a major report to the G-10 Governors assessing the relative costs and benefits of the rapid expansion in derivatives markets, and concluded that enhanced oversight and better management at the level of the firm was preferable to increased regulation. The Fisher (BIS: ECSC, 1994a), Hannoun (BIS: ECSC, 1994b) and Brockmeijer Reports (BIS: ECSC, 1995) were the direct products of this initiative. Around the same time, and building on suggestions made by the Group of Thirty, the Basle Supervisors, together with IOSCO, issued comprehensive risk management guidelines for use in the examination of banks' and securities firms' derivative operations (BIS: Basle Committee on Banking Supervision, 1995c).

To support its work, the Euro-currency Standing Committee has been instrumental in collecting data on international banking and debt developments (an initiative put in place just before the Mexican debt crisis of 1982). This data is receiving renewed attention in light of the most recent Mexican crisis, and important extensions to the current data set are being contemplated. The 
usefulness of the data for balance-of-payments purposes is also being increasingly recognised by the IMF and national data compilers. Under the influence of the Committee, the triennial survey of foreign exchange activity (begun in 1986) has just been extended to cover all derivative instruments as recommended in the Brockmeijer Report. It now seems likely that there will also be a half-yearly survey of the consolidated balance sheets of major participants in the derivatives markets, with a view to more closely monitoring developments in this important area.

There have also been a number of agreements reached with respect to the third dimension of the systemic risk matrix; the infrastructure behind it. In the measure the agreements have had to do with clarifying legal issues, this has been dealt with in Section 3. Strengthening the operational integrity of payment systems and improving the management of settlement risk have been key preoccupations of central banks, and especially the Committee on Payment and Settlement Systems (CPSS) which also reports to the G-10 Governors (BIS: CPSS, 1993b). The focus has been on the large-value-transfer systems between banks, both domestic and cross-border (BIS: CPSS, 1993a), which usually involve final settlement on accounts maintained with the central banks. Foreign exchange transactions, easily the largest proportion of cross-border payments, and the cash-legs of securities transactions, are settled through these systems. G-10 central banks, through the CPSS, have agreed and implemented a number of operational measures to contain risks and increase efficiency in these arrangements (e.g. the Lamfalussy Standards; see BIS: CPSS, 1990). Similar measures have since been adopted in some non-G-10 countries, notably in the European Union.

More recently, the CPSS has examined clearing and settlement arrangements for securities transactions (BIS: CPSS, 1995). Many central banks play a prominent operational role in such arrangements for government securities, and all take an active interest in those for government as well as corporate securities. Volumes in these systems, domestic as well as cross-border, have increased very rapidly. Efforts in this area have sought to shorten settlement cycles and to strengthen mechanisms for the orderly completion of transactions (e.g. delivery-versus-payment. BIS: CPSS, 1992). This work continues in cooperation with the private sector. Finally, the CPSS is also studying the clearing and settlement arrangements for exchange-traded derivatives.

The most recent agreement reached in the CPSS has to do with foreign exchange settlement risk (or Herstatt risk; see BIS: CPSS, 1996). Extensive investigations in all the major 
financial sectors revealed that foreign exchange settlement exposure is not just an intra-day phenomenon as previously thought. Rather, exposure often lasts for some days and the amount at risk to a single counterparty commonly exceeds the banks' capital. If this is the bad news, the good news is that banks could eliminate most of this exposure by changing their own internal practices and correspondent banking arrangements, and by introducing obligation netting capabilities and proper risk management controls. Nevertheless, a remaining problem is that many banks remain sceptical about devoting substantial resources to such efforts, largely because they think the risk of something going wrong is very low. To the extent this view rests on the belief that the authorities will always step in to avoid crises, this view cannot be left unchallenged. Accordingly, the G-10 Governors have agreed on a strategy to encourage the private sector to find solutions, either through action at the level of individual banks or through some well constructed multi-currency service.

Bilateral netting schemes for foreign exchange contracts, such as FX NET and ICSI, have been in operation for a number of years. FX NET is a system run by several large banks for the bilateral netting by novation of spot and forward foreign exchange contracts. The system started in 1987 in London, was then extended to banks operating in the United States, and now also covers institutions in the main East Asian financial centres and in Paris and Zurich. The service allows netting both within and between centres. International Clearing Systems Inc. (ICSI) was launched in July 1992 by initially eight Canadian and US banks. There are plans to upgrade the service to mulitlateral netting. ECHO, a multilateral clearing arrangement for FX transactions, began operation in London in 1995 and a similar arrangement, Multinet, is being introduced in North America. The announcement in February of a private sector plan to establish a global clearing bank to handle foreign exchange transactions is another important development. Properly constructed and operated, such arrangements can reduce settlement exposures, but can concentrate them if this is not the case. The central banks concerned and the CPSS have examined these arrangements in the light of the Lamfalussy Standards, and the Basle Committee has recently agreed upon the capital treatment that would apply to banks' exposures in netting schemes (BIS: Basle Committee on Banking Supervision, 1996b).

It is finally worth noting that each of the three Standing Committees reporting to the G-10 Governors on matters pertaining to financial stability has taken steps to involve countries 
outside the Group of Ten. The Supervisors organise a Biennial meeting and have ongoing relations with regional groups of supervisors around the world. Last year, the CPSS expressed the same desire to involve others and, in addition to providing more seminars for regional groups and organising meetings for non-members at the BIS, has already established a technical working group with a solid group of non G-10 participants. Finally, the Euro-currency Standing Committee has for many years held extended meetings including non-members who support the statistics-gathering exercises sponsored by the Committee. The challenge now will be to extend these contacts, and to allow for substantive input at an earlier stage, while retaining the smallness and informality which have facilitated the achievement of agreements in so many areas.

\section{Crisis management and crisis resolution}

It is fair to say that in most countries there are no predetermined, formal procedures for managing domestic financial crises with potential systemic implications. ${ }^{30}$ There are general understandings about the conditions under which the central bank should act as lender of last resort, but the significant degree of judgement that can still be applied implies a state of "constructive ambiguity" about what the central bank's response might be in different circumstances. Nor is the central bank likely to be the only part of the public sector involved. Treasuries, deposit insurance agencies and various supervisory bodies may all have legitimate interests in a crisis. Perhaps the only agreement that can be reached in advance is that the parties likely to be drawn into such a crisis should know each other and their respective objectives very well. This will help speed discussions and decisions under stressful circumstances when there is likely to be little time for lengthy deliberations. ${ }^{31}$

The same points apply still more strongly at the international level. There are no formal agreements, but a general understanding does exist that the home country central bank is expected in the first instance to support its own financial institutions, wherever they operate. The agreement between the Federal Reserve last year and the Bank of Japan under which the Bank of Japan could obtain ready dollar funds against repos with the Federal Reserve, is a manifestation of such an

30 Recall that risk controls in payment and settlement systems - based on agreed liquidity facilities, loss-sharing agreements or other pledging of collateral - would prove very helpful in a crisis. This has more to do with crisis prevention than crisis management.

31 See Fisher, Roger and William Ury (1981). 
understanding. However, firm, prior commitments to particular patterns of official behaviour would only invite bad behaviour and moral hazard on the part of the private sector. In this regard, it is already bad enough that the public sector does sometimes have to get directly involved; for example in the case of the stock market crash in 1987, when a number of central banks provided liquidity support to various firms severely affected by it. Rather, as at the domestic level, the important thing is that those institutions and individuals likely to be affected by the crisis should know each other well and have well-established lines of communication in place. Fortunately, the international meetings which take place at the IMF, BIS and OECD, and in many other fora, serve this general purpose as well as more particular ones.

Turning for completeness to the issue of crisis resolution, this term normally refers to the orderly winding-up of the affairs of an international financial institution. The Bank of Credit and Commerce International S.A. (BCCI) affair ${ }^{32}$ made it clear that the laws of different countries need to be harmonised in some way. The UK and European authorities were of the view that the global assets of BCCI would be available to the liquidators. In contrast, US law made it appropriate for BCCI assets in the United States to be seized and used to offset liabilities to US citizens. At the level of principle, the global approach might seem the more appropriate one, but national legislation (particularly in the United States) will be required to put this into effect. As indicated by the experience of the major European countries, which tried and failed to harmonise their bankruptcy laws, this could take some time.

\section{Outstanding issues pertaining to financial stability}

This Survey of International Agreements indicates how much has already been done to facilitate cross-border business, to extend cross-border competition and to promote financial stability. Two important observations can be made about these accomplishments. Progress has been greatest with respect to the financial markets of G-10 countries but other countries are also becoming increasingly involved in international financial markets. Moreover, the pace of change continues to accelerate as

32 The headquarters of the parent holding of the BCCI were in Luxembourg, and the two largest subsidiaries were in Luxembourg and the Cayman Islands. The global business in sixty-nine countries was orchestrated out of the London office. Regulatory authorities from a number of countries took control of BCCI banks on 5th July 1991, as an initial step prior to liquidation. 
international agreements, increased trade, technological progress, competition and domestic deregulation interact to promote the process of change.

These observations lead on directly to two sets of outstanding issues having to do with international agreements directed to enhancing financial stability. The first set of issues has to do with participation in international financial agreements. Non-G-10 countries will increasingly have to be consulted, and given the capacity to influence decisions that will have a global impact. What is not yet clear is how this can be done in a way that preserves the great merits of "international cooperation based on home country control"; that is, informal discussions between a tractable number of national representatives, each of whom can speak authoritatively for the national interest while recognising the need for an agreement at the end of the day. A closely related point having to do with participation is the breakdown of sectoral barriers and the consequent need for various kinds of supervisors to interact. They must more fully inform each other about worrisome developments, as well as reach agreements about the operations of international conglomerates. Work here has only just begun, though the establishment of the Joint Forum and the promulgation of the Windsor Declaration ${ }^{33}$ have been important recent steps forward.

The second point has to do with the accelerating pace of change, and the increased difficulty that regulators have in keeping up to date. Closely related is the fact that profits in the financial system will be under increasing pressure from enhanced competition. If the past provides any guide to the future, there will be an increased tendency for firms to try to enhance profits by taking more risks. The implication is that supervisors, in industrial countries at least, will come to rely more on disclosure, internal models and market discipline as a complement to more traditional techniques of oversight. New international agreements will thus be required to specify guidelines as to how such disclosure might best be carried out. The increased reliance on market discipline also implies a need for progress in harmonising the accounting standards problem as well as agreement to standardise procedures for dealing with the bankruptcy of internationally active financial firms.

33 The Windsor Declaration of 17th May 1995 was issued by representatives of regulatory bodies in 16 countries having responsibility for the supervision of the world's major futures and options markets. They agreed to a large number of points, including information sharing, customer protection, default procedures and cooperation in emergencies. This step forward was also the result of a crisis, the failure of Barings and the revelation that Nick Leeson's open positions on each of two exchanges was not known by the regulatory body of the other exchange. 
Disclosure can be particularly helpful in encouraging market discipline when it allows firms' behaviour to be compared by rating agencies and others against standards for prudent operations, such as defined by supervisors. This leads to the proposal that market discipline in developing economies might be enhanced by having some international agreement as to what constitutes prudent behaviour. At the moment, there is no such agreement. Since banks in a number of developing countries seem to be going down the same speculative route as did the banks in many industrial countries in the 1980 s, particularly with respect to the excessive growth of credit related to property, some jointly developed guidelines in this particular area might be useful. As with disclosure pertaining to the use of derivatives, a positive dynamic might be established were even a small number of large, emerging countries to participate in such an experiment. Supervisors would be expected to sign on to such standards and to enforce them, or at the least give the market convincing reasons why not.

A third issue has to do with the issue of upstream and downstream relations between financial firms and commercial companies, and the inadvertent extension of the safety net. More broadly, the whole question of safety net provisions needs review given the way in which they can increase moral hazard risks overall by encouraging risky behaviour and by inducing firms to move to jurisdictions where the safety net is widest. In this context, the question of "narrow banking" is once again receiving attention in certain developing countries.

A fourth area where further improvements are needed is in the "plumbing" which supports the international financial system; in particular, payment systems must be further improved such that payment with finality can be counted upon, "regardless". Improvements in this area will have to be incremental and primarily based on the input of the industry responding to its own self interest. As indicated in the recent suggestions concerning Herstatt risk, the role of the public sector is not to take on the responsibility itself. In addition, incremental changes will be required to improve the specification of capital adequacy ratios over time, as well as further investigation of complementary means to ensure the prudent governance of financial institutions. This is a topic which is receiving increasing attention in the academic literature. ${ }^{34}$

\footnotetext{
34 See, for example, Hellwig (1995), Estrella (1995) and Gehrig (1995).
} 
Finally, it is also worth noting, yet again for a central banker, that the biggest factor contributing to financial stability is macroeconomic stability. Periods of high and rising inflation, or uncertainty about the sustainability of fiscal positions, encourage behaviour likely to contribute to financial instability. This is an important lesson from the experience of developed countries in the 1970s and 1980s. A complementary lesson from the 1990s, in particular the recent experience of Mexico, is that financial instability can contribute significantly to macroeconomic instability. Such experiences help to explain why the business of central banking almost everywhere is increasingly focused on ensuring both price and financial stability. 


\section{References}

Andersen, Palle and William R. White (1996): "The Macroeconomic Effects of Financial Sector Reforms: An Overview of Industrial Countries". Paper presented at an OECD conference on Interactions Between Structural Reform, Macroeconomic Policies and Economic Performance, Paris, 18th-19th January.

Bank for International Settlements (1994): 64th Annual Report, June.

Bank for International Settlements (1995): 65th Annual Report, June.

Bank for International Settlements (1996a): Financial Market Volatility: Measurement, Causes and Consequences, March.

Bank for International Settlements (1996b): Central Bank Survey of Foreign Exchange and Derivatives Market Activity 1995, May.

Bank for International Settlements (1996c): 66th Annual Report, June.

Bank for International Settlements: Basle Committee on Banking Supervision (1975): Report on the Supervision of Banks' Foreign Establishments.

Bank for International Settlements: Basle Committee on Banking Supervision (1992): Minimum Standards for the Supervision of International Banking Groups and Their Cross-Border Establishments, July.

Bank for International Settlements: Basle Committee on Banking Supervision (1995a): Planned Supplement to the Capital Accord to Incorporate Market Risks, April.

Bank for International Settlements: Basle Committee on Banking Supervision (1995b): An Internal Model-Based Approach to Market Risk Capital Requirements, April.

Bank for International Settlements: Basle Committee on Banking Supervision (1995c): Framework for Supervisory Information about the Derivatives Activities of Banks and Securities Firms. Joint Report by the Basle Committee on Banking Supervision and the Technical Committee of the IOSCO, May.

Bank for International Settlements: Basle Committee on Banking Supervision (1995d): The Supervision of Financial Conglomerates, July.

Bank for International Settlements: Basle Committee on Banking Supervision (1995e): Public disclosure of banks and securities firms. Joint Report by the Basle Committee on Banking Supervision and the Technical Committee of the IOSCO, November.

Bank for International Settlements: Basle Committee on Banking Supervision (1996a): The Supervision of Cross-Border Banking. Report by a working group comprised of members of the Basle Committee on Banking Supervision and the Offshore Group of Banking Supervisors, March.

Bank for International Settlements: Basle Committee on Banking Supervision (1996b): Interpretation of the Capital Accord for the Multilateral Netting of Forward Value Foreign Exchange Transactions, April. 
Bank for International Settlements: Committee on Payment and Settlement Systems (1990): Report of the Committee on Interbank Netting Schemes of the Central Banks of the Group of Ten Countries (Lamfalussy Report), November.

Bank for International Settlements: Committee on Payment and Settlement Systems (1992): Delivery Versus Payment in Securities Settlement Systems, September.

Bank for International Settlements: Committee on Payment and Settlement Systems (1993a): Central Bank Payment and Settlement Services with Respect to Cross-Border and Multi-Currency Transactions (Noël Report), September.

Bank for International Settlements: Committee on Payment and Settlement Systems (1993b): Payment Systems in the Group of Ten Countries, December.

Bank for International Settlements: Committee on Payment and Settlement Systems (1995): CrossBorder Securities Settlements, March.

Bank for International Settlements: Committee on Payment and Settlement Systems (1996): Settlement Risk in Foreign Exchange Transactions, March.

Bank for International Settlements: Euro-currency Standing Committee (1986): Recent Innovations in International Banking (Cross Report), April.

Bank for International Settlements: Euro-currency Standing Committee (1994a): A Discussion Paper on Public Disclosure of Market and Credit Risks by Financial Intermediaries (Fisher Report), September.

Bank for International Settlements: Euro-currency Standing Committee (1994b): Macroeconomic and Monetary Policy Issues Raised by the Growth of Derivatives Markets (Hannoun Report), November.

Bank for International Settlements: Euro-currency Standing Committee (1994c): Compendium of Annexes to the Report on Macroeconomic and Monetary Policy Issues Raised by the Growth of Derivatives Markets (Hannoun Report), November.

Bank for International Settlements: Euro-currency Standing Committee (1995): Issues of Measurement Related to Market Size and Macroprudential Risks in Derivatives Markets (Brockmeijer Report), February.

Canada: Department of External Affairs (1987): The Canada-US Free Trade Agreement. Ottawa.

Eichengreen, Barry and Richard Portes (1995): Crisis? What Crisis? Orderly Workouts for Sovereign Debtors. London: CEPR.

Estrella, Arturo (1995): "A Prolegomenon to Future Capital Requirements". FRBNY Economic Policy Review, July.

Federal Reserve Bank of New York (1995): Principles and Practices for Wholesale Financial Market Transactions.

Fisher, Roger and William Ury (1981): Getting to Yes: Negotiating Agreement Without Giving In. Boston: Houghton Mifflin Co. 
Folkerts-Landau, David and Takatoshi Ito (1995): International Capital Markets: Developments, Prospects and Policy Issues. Washington: International Monetary Fund.

Gehrig, Thomas (1995): "Capital Adequacy Rules: Implications for Banks' Risk-Taking". Paper presented at a conference on Capital Adequacy Rules as Instruments for the Regulation of Banks, Basle University, 7th July.

Group of Ten (1996): The Resolution of Sovereign Liquidity Crises. A Report to the Ministers and Governors Prepared under the Auspices of the Deputies, May.

Group of Thirty (1993): "Derivatives: Practices and Principles". Washington, D.C., July.

Heinrich, Gregor (1996): "Fund Transfers, Payments and Payment Systems - International Initiatives Towards Legal Harmonisation", in Recht des grenzüberschreitenden Zahlungsverkehrs im Binnenmarkt, edited by W. Hadding and U.H. Schneider, to be published by Europäische Rechtsakademie, Trier.

Hellwig, Martin (1995): "Systemic Aspects of Risk Management in Banking and Finance". Paper presented at a conference on Capital Adequacy Rules as Instruments for the Regulation of Banks, Basle University, 7th July.

Institute for International Finance (1994): "A Preliminary Framework for Public Disclosure of Derivatives Activities and Related Credit Exposures". Washington, D.C., August.

Kapstein, Ethan B. (1992): "Between Power and Purpose: Central Bankers and the Politics of Regulatory Convergence". International Organization 46(1, Winter), pp. 265-287.

Kapstein, Ethan B. (1994): Governing the Global Economy. Cambridge, MA: Harvard University Press.

Organisation for Economic Co-operation and Development (1993): Market Access for Foreign Financial Institutions. DAFFE/CMF(93)22.

United Kingdom: Securities and Investment Board (1995): Windsor Declaration, 16th-17th May.

United States of America: Commodity Futures Trading Commission (1995): Windsor Declaration, 16th-17th May.

White, William R. (1994a): "The Implications of the FTA and NAFTA for Canada and Mexico". Bank of Canada, Technical Report No. 70.

White, William R. (1994b): "Systemic Risk and Derivatives: Can Disclosure Help?". Keynote address for the London School of Economics conference on The Implications of Derivatives for Regulation, London, 2nd December.

World Trade Organization (1995a): The WTO Agreement on Financial Services. Press Release, 26th July.

World Trade Organization (1995b): "Results of the Negotiations on Financial Services". Report on the Extended Negotiations Conducted under the Second Annex on Financial Services of the GATS and the Ministerial Decision on Financial Services, 6th September. 


\section{Recent BIS Working Papers}

No.

23

October 1994

24

April 1995

25

April 1995

26

April 1995

27

May 1995

28

August 1995

29

September 1995

30

November 1995

31

December 1995

32

December 1995

33

January 1996

34

January 1996

35

July 1996

36

August 1996

37

September 1996
Title

The changing borders of banking: trends and implications

The structure of credit to the non-government sector and the transmission mechanism of monetary policy: a cross-country comparison

A survey of non-financial sector balance sheets in industrialised countries: implications for the monetary policy transmission mechanism

The monetary transmission mechanism: evidence from the G-7 countries

The response of short-term bank lending rates to policy rates: a cross-country perspective

The term structure of Euro-rates: some evidence in support of the expectations hypothesis

The information content of the term structure: evidence for Germany

Money demand stability and currency substitution in six European countries (1980-1992)

Testing the quantity theory using long-run averaged cross-country data

The anatomy of the bond market turbulence of 1994

Derivatives and asset price volatility: a test using variance ratios

Monetary policy and the behaviour of interest rates: are long rates excessively volatile?

Varieties of monetary policy operating procedures: balancing monetary objectives with market efficiency

Estimation of speculative attack models: Mexico yet again

Does the term structure predict recessions?

The international evidence
Author

Claudio E.V.Borio

and Renato Filosa

Claudio E.V. Borio

John T. Kneeshaw

Stefan Gerlach and Frank Smets

Claudio E.V. Borio and Wilhelm Fritz

Stefan Gerlach and Frank Smets

Stefan Gerlach

Renato Filosa

Stefan Gerlach

Claudio E.V. Borio

Robert N. McCauley

Benjamin H. Cohen

Stefan Gerlach

Joseph Bisignano

William R. Melick

Henri Bernard and Stefan Gerlach 